\title{
DAMAGE TOLERANCE STUDY OF HONEYCOMB SANDWICH STRUCTURE
}

\author{
Reshma Babu', Sunil Kumar G' ${ }^{2}$, Atul Kumar ${ }^{3}$, P. Eapen Sakaria ${ }^{4}$ \\ ${ }^{l}$ M. Tech Student, Department of Civil Engineering, SAINTGITS College of Engineering, Kerala, India \\ ${ }^{2}$ Scientist, Vikram Sarabhai Space Centre (ISRO), Trivandrum, Kerala, India \\ ${ }^{3}$ Scientist, Vikram Sarabhai Space Centre (ISRO), Trivandrum, Kerala, India \\ ${ }^{4}$ Professor of PG Studies, Department of Civil Engineering, SAINTGITS College of Engineering, Kerala, India
}

\begin{abstract}
Composite materials are essential component in today's modern world. Structural sandwich construction is one of the first form of composite structures. In this study honeycomb sandwich structure which is a peculiar type of composite structure was investigated for crashworthiness. They are manmade structures with a honeycomb geometry. It consists of three elements ; Top face sheet, Core, Bottom face sheet. They are widely used in aerospace industry, marine, rail, automotive industry, in construction field as prefabricated partition walls, mezzanine floor, doors etc. The main objective of this study was to assess the damage tolerance of honeycomb sandwich structure based on serviceability and safety of the structure ie. to understand ability of structure to sustain defects safely until repair/replacement is performed. Damage tolerance study was performed to know with how much load this structure would safely withstand and also to know till how much load this structure would be made serviceable, if a damage is caused to it. Investigations were performed on both damaged and undamaged specimens by conducting. Four point bending flexure test and Edgewise compression test based on ASTM standards. Also finite element modeling of honeycomb sandwich structure was developed and analysis of the two experiments were performed in Ansys. Ultimate load, tensile and compressive stress values etc. obtained from the two experiments were compared for both damaged and undamaged specimen. Based on the results obtained it could be inferred that the load carrying capacity of honeycomb sandwich structure reduces, if a damage is caused to it but can perform its duty with reduced efficiency.
\end{abstract}

Keywords: Honeycomb Sandwich, Crashworthiness, Four point bending and Edgewise compression.

\section{INTRODUCTION}

Composite materials are broadly used in today's modern world. In this study Honeycomb sandwich Structures, which is a peculiar type of composite structure was investigated for understanding its damage tolerance capacity. Damage tolerance study was performed to know with how much load this structure would safely withstand and also to know till how much load this structure would be made serviceable, if a damage is caused to it. Honeycomb sandwich structures are manmade structures with a honeycomb geometry. It provides a core material with minimal density and ease of fabrication. It is widely used were high specific stiffness are valuable. They are popularly used in aerospace industry, construction field as prefabricated partition walls, mezzanine floor, doors etc. Investigations were performed on the basis of different experimental program and finite element analysis. Four point bending flexure test and Edgewise compression test are the two experiments performed in this study. Also finite element modeling of honeycomb sandwich structure for the two experiments were developed and analyzed. Studies were done on both damaged and undamaged specimens of honeycomb sandwich structure and the results were compared.

\section{OBJECTIVES}

The objective of the study was to assess the damage tolerance of honeycomb sandwich structure based on serviceability and safety of the structure if a damage is caused to it. ie. to understand ability of structure to sustain defects safely until repair/replacement is performed. The main purpose was to know how much load the structure could withstand if damage is present.

\section{METHODOLOGY}

1. Performing four point bending flexure test and edgewise compression test for both undamaged and damage specimens of honeycomb sandwich structure.

2. Developing finite element model of both undamaged and damaged honeycomb sandwich structure in Ansys.

3. Foundation Simulation of both the experiments using model created in Ansys.

\section{EXPERIMENTAL STUDY}

Two types of mechanical tests, Four point bending flexure test and edgewise compression test were done using universal test machine based on ASTM standards. ASTM standards C393/C393M and C364/364M were used for Four point bending flexure test and edgewise compression test respectively. Experimental program was done to study and compare the behavior of undamaged and damaged 
honeycomb sandwich structure. Specimens fabricated in W direction (transverse direction) were used as its local core shear failure tendency was more in this direction. Aluminum alloy (AA2014) for face sheet and Aluminum alloy (AA5056) hexagonal aluminum honeycomb for core and epoxy thermosetting resin for bonding three layers were used to fabricate honeycomb sandwich panels. One specimen each for both undamaged and damaged honeycomb sandwich structure was tested for each experiment.

\subsection{Four Point Bending Flexure Test}

Table - 1: Size of specimen used for four point bending test as per ASTM standards

\begin{tabular}{|l|l|l|l|}
\hline \multicolumn{3}{|l|}{ Size of specimen } \\
\hline $\begin{array}{l}\text { Length } \\
(\mathrm{mm})\end{array}$ & $\begin{array}{l}\text { Width } \\
(\mathrm{mm})\end{array}$ & $\begin{array}{l}\text { Face sheet } \\
\text { Thickness } \\
(\mathrm{mm})\end{array}$ & $\begin{array}{l}\text { Core } \\
\text { Thickness } \\
(\mathrm{mm})\end{array}$ \\
\hline 375 & 50 & 1 & 22.86 \\
\hline
\end{tabular}

The damage in honeycomb sandwich structure was created at a distance of $10 \mathrm{~mm}$ from the centre of the specimen in the form of a $6 \mathrm{~mm}$ size dent by providing compressive load by universal test machine using a $40 \mathrm{~mm}$ diameter ball. In this experiment failure of the specimen occurs due to flexure. The ultimate load due to flexure and tensile strength $(\sigma)$ for ultimate load, $F$ and cross sectional area of the specimen, A for both damaged and undamaged specimen were calculated by the following equation;

$\sigma=\mathrm{F} / \mathrm{A}$

\subsection{Edgewise Compression Test}

Table - 2: Size of specimen used for edgewise compression test as per ASTM standards

\begin{tabular}{|l|l|l|l|}
\hline \multicolumn{3}{|l|}{ Size of specimen } \\
\hline $\begin{array}{l}\text { Length } \\
(\mathrm{mm})\end{array}$ & $\begin{array}{l}\text { Width } \\
(\mathrm{mm})\end{array}$ & $\begin{array}{l}\text { Face sheet } \\
\text { Thickness } \\
(\mathrm{mm})\end{array}$ & $\begin{array}{l}\text { Core } \\
\text { Thickness } \\
(\mathrm{mm})\end{array}$ \\
\hline 240 & 70 & 1 & 22.86 \\
\hline
\end{tabular}

In this test face sheet takes the load applied. Damage in honeycomb sandwich structure was created at the centre of the specimen in the form of a $6 \mathrm{~mm}$ size dent by providing compressive load by universal testing machine by placing a $40 \mathrm{~mm}$ diameter ball. In this experiment failure of the specimen occurs due to buckling. The ultimate load due to buckling and face sheet compressive stress $(\sigma)$ for ultimate load, $\mathrm{P}$ and area of both facings, A for both damaged and undamaged specimen were calculated by the following equation;

$\sigma=\mathrm{P} / \mathrm{A}$

\section{FINITE ELEMENT MODELING OF HONEYCOMB SANDWICH STRUCTURE}

Finite element analysis of honeycomb sandwich structure was performed in Ansys. It was modeled using SHELL 181 element type for both face sheets and core. The two layers of the face sheets were assigned with Aluminum alloy (AA2014T6) properties. Young's modulus, E of $70000 \mathrm{MPa}$ and poisson's ratio of 0.33 were assigned to the face sheets. Core was assigned with Aluminum Alloy (AA5056) hexagonal honeycomb properties. Upper and lower face sheets and regular hexagonal core of cell size $6 \mathrm{~mm}$ and cell foil thickness of $0.5 \mathrm{~mm}$ were created in $\mathrm{W}$ direction for both the experiments in Ansys. Analysis were performed for the ultimate load obtained from the experiments for both undamaged and damaged specimen. Eigen buckling analysis was performed for edgewise compression test as in this test specimen fails due to buckling. Finite element model were same for both damaged and undamaged specimen. The stiffness of the damaged zone is very low compared to the undamaged structure and hence reduced value for Young's Modulus was used for the simulation of the damage. The effect of damage in the model was created by introducing a new material property with young's modulus, $\mathrm{E}=70 \mathrm{MPa}$ which is a low value and the area where damaged has occurred was assigned with this new material property for both the tests.

\section{RESULTS AND DISCUSSIONS}

\subsection{Four Point Bending Flexure Test}

Table - 3: Data obtained from four point bending test (undamaged specimen)

\begin{tabular}{|l|l|l|l|}
\hline Sl. No. & Load $(\mathrm{kN})$ & Deflection(mm) & Strain \\
\hline 1 & 0.50 & 0.14 & $221 \times 10^{-6}$ \\
\hline 2 & 1.00 & 0.33 & $459 \times 10^{-6}$ \\
\hline 3 & 1.50 & 0.48 & $663 \times 10^{-6}$ \\
\hline 4 & 2.00 & 0.64 & $906 \times 10^{-6}$ \\
\hline 5 & 2.25 & 0.75 & $1001 \times 10^{-6}$ \\
\hline 6 & 2.50 & 0.82 & $1119 \times 10^{-6}$ \\
\hline 7 & 2.75 & 0.98 & $1238 \times 10^{-6}$ \\
\hline 8 & 3.00 & 1.10 & $1348 \times 10^{-6}$ \\
\hline 9 & 3.25 & 1.15 & $1466 \times 10^{-6}$ \\
\hline 10 & 3.50 & 1.20 & $1590 \times 10^{-6}$ \\
\hline
\end{tabular}

Ultimate Load Due to Flexure $=3.5 \mathrm{kN}$ 


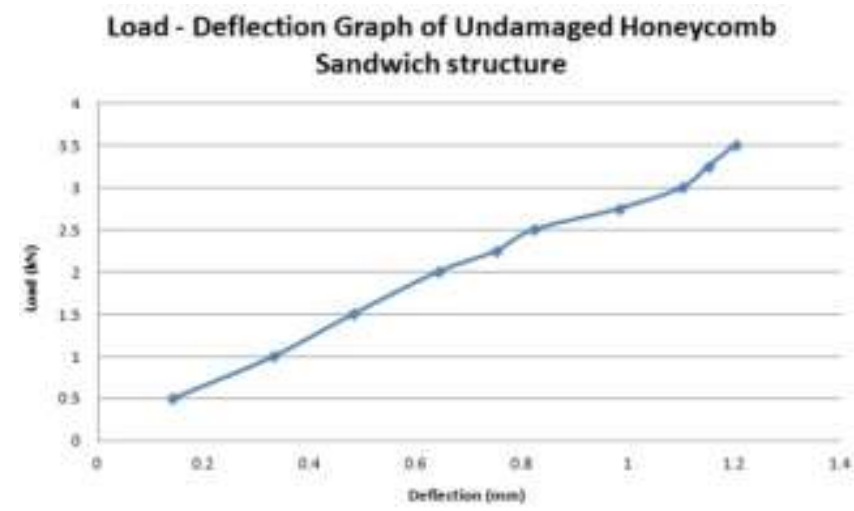

Fig-1: Load-Deflection curve of undamaged honeycomb sandwich structure for four point bending flexure test

The ultimate load obtained for undamaged specimen was 3.5 $\mathrm{kN}$ and corresponding $1.2 \mathrm{~mm}$ as deflection and $1590 \times 10^{-6}$ as strain value. The tensile strength, $\sigma$ obtained was 0.19 $\mathrm{N} / \mathrm{mm}^{2}$. Finite element analysis was performed for the ultimate load of $3.5 \mathrm{kN}$ obtained from experimental results. Deflection for a load of $3.5 \mathrm{kN}$ from analysis was $1.17 \mathrm{~mm}$ whereas the experimental value of deflection for the same load was $1.2 \mathrm{~mm}$. Strain value from analysis was $1551 \mathrm{x}$ $10^{-6}$ whereas the experimental value was $1590 \times 10^{-6}$.Thus the experimental and analysis values obtained for four point bending flexure test for specimens without damage were in good match with $2.5 \%$ variation.

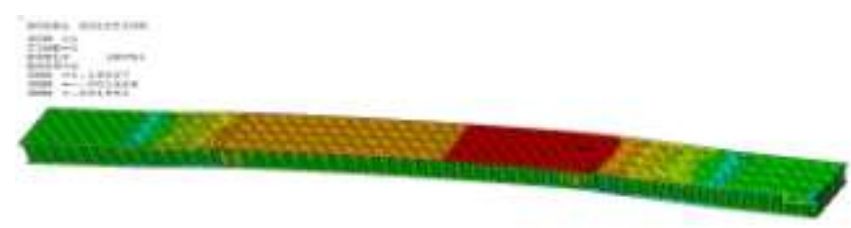

Fig - 2 Finite Element Analysis of undamaged honeycomb sandwich structure for four point bending flexure test

Table - 4: Data obtained from four point bending flexure test (damaged specimen)

\begin{tabular}{|l|l|l|l|}
\hline $\begin{array}{l}\text { Sl. } \\
\text { No. }\end{array}$ & $\begin{array}{l}\text { Load } \\
(\mathrm{kN})\end{array}$ & $\begin{array}{l}\text { Deflection } \\
(\mathrm{mm})\end{array}$ & Strain \\
\hline 1 & 0.50 & 0.15 & $96 \times 10^{-6}$ \\
\hline 2 & 1.00 & 0.40 & $130 \times 10^{-6}$ \\
\hline 3 & 1.50 & 0.62 & $158 \times 10^{-6}$ \\
\hline 4 & 2.00 & 0.90 & $187 \times 10^{-6}$ \\
\hline 5 & 2.25 & 1.01 & $208 \times 10^{-6}$ \\
\hline 6 & 2.50 & 1.15 & $233 \times 10^{-6}$ \\
\hline 7 & 2.75 & 1.25 & $260 \times 10^{-6}$ \\
\hline 8 & 3.00 & 1.39 & $283 \times 10^{-6}$ \\
\hline 9 & 3.25 & 1.50 & $315 \times 10^{-6}$ \\
\hline 10 & 3.50 & 1.90 & $303 \times 10^{-6}$ \\
\hline Ultimate Load Due to Flexure $=3.5 \mathrm{kN}$ \\
\hline
\end{tabular}

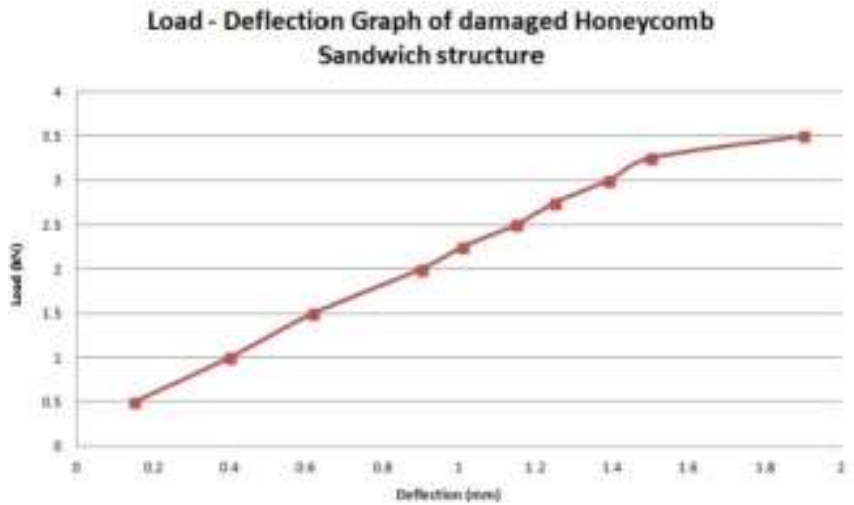

Fig-3: Load-Deflection curve of damaged honeycomb sandwich structure for four point bending flexure test

The ultimate load obtained for damaged specimen was 3.5 $\mathrm{kN}$ and corresponding $1.9 \mathrm{~mm}$ as deflection and $303 \times 10^{-6}$ as strain value. The ultimate load and tensile strength obtained for both undamaged and damaged specimens were same. This was due to the fact that the damaged was present in between the support region and shear force between the support region is zero.

\subsection{Edgewise Compression Test}

Table - 5: Data obtained from edgewise compression test

\begin{tabular}{|l|l|l|}
\hline $\begin{array}{l}\text { Sl. } \\
\text { No. }\end{array}$ & $\begin{array}{l}\text { Load } \\
(\mathrm{kN})\end{array}$ & $\begin{array}{l}\text { Deflection } \\
(\mathrm{mm})\end{array}$ \\
\hline 1 & 5 & 0.31 \\
\hline 2 & 10 & 0.38 \\
\hline 3 & 15 & 0.47 \\
\hline 4 & 20 & 0.62 \\
\hline 5 & 25 & 0.69 \\
\hline 6 & 30 & 0.76 \\
\hline 7 & 35 & 0.83 \\
\hline 8 & 40 & 0.91 \\
\hline 9 & 45 & 1.02 \\
\hline 10 & 50 & 1.11 \\
\hline 11 & 50.28 & 1.19 \\
\hline $\begin{array}{l}\text { Ultimate load due to skin to core } \\
\text { failure at the edges }=50.28 \mathrm{kN}\end{array}$ \\
\hline
\end{tabular}

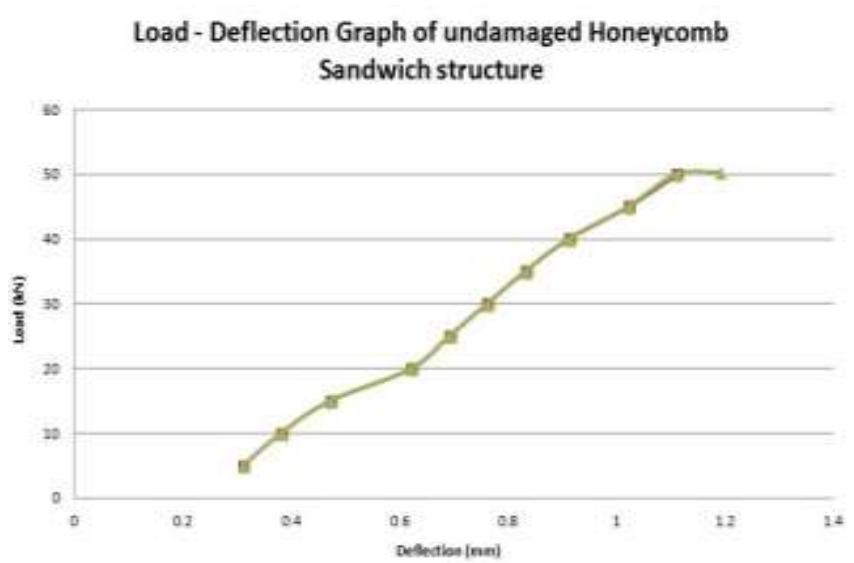

Fig-4: Load-Deflection curve of undamaged honeycomb sandwich structure for Edgewise Compression test 
Ultimate load due to skin to core failure at edge for undamaged specimen is $50.28 \mathrm{kN}$. Face sheet compressive stress, obtained was $1.5 \mathrm{kN}$. In the edgewise compression test, face sheets are the main load carrying members. The core materials increase the strength of the system by coupling the face sheets and increasing the buckling capacity. Face sheet buckling within the sandwich panel took place with the de-bonding of the core and face sheets at the edge in contact with the crossheads. Failure occurred due to shear at the interface between the core and the face sheet on the compression side of the core. On the tension side, the core remained bonded to the face sheet.

Eigen buckling analysis was performed as specimen fails due to buckling in edgewise compression test. Linear buckling (also called as Eigen value buckling) analysis predicts the theoretical buckling strength of an ideal elastic structure. In buckling analysis buckling load factor will be obtained which has to be multiplied to the load applied in static analysis. The analysis was performed for the ultimate load of $50.28 \mathrm{kN}$ obtained from experiment. The value obtained as buckling load factor was 1.Thus the experimental and analysis values were in good match.
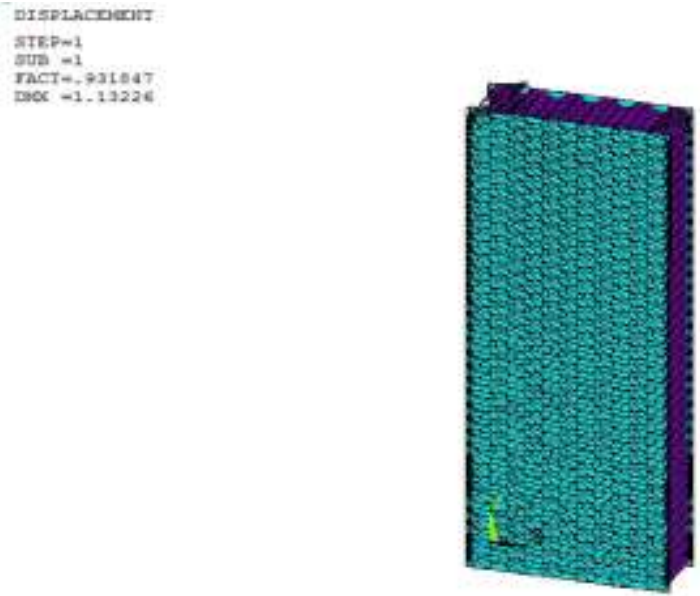

Fig - 5 Buckling analysis of undamaged specimen for edgewise compression test

Table - 6: Data obtained from edgewise compression test (damaged specimen)

\begin{tabular}{|l|l|l|}
\hline $\begin{array}{l}\text { Sl. } \\
\text { No. }\end{array}$ & $\begin{array}{l}\text { Load } \\
(\mathrm{kN})\end{array}$ & $\begin{array}{l}\text { Deflection } \\
(\mathrm{mm})\end{array}$ \\
\hline 1 & 5 & 0.28 \\
\hline 2 & 10 & 0.43 \\
\hline 3 & 15 & 0.52 \\
\hline 4 & 20 & 0.73 \\
\hline 5 & 25 & 0.93 \\
\hline 6 & 29.32 & 1.10 \\
\hline \multicolumn{3}{|l|}{$\begin{array}{l}\text { Buckling load for damaged } \\
\text { specimen = 29.32 kN }\end{array}$} \\
\hline
\end{tabular}

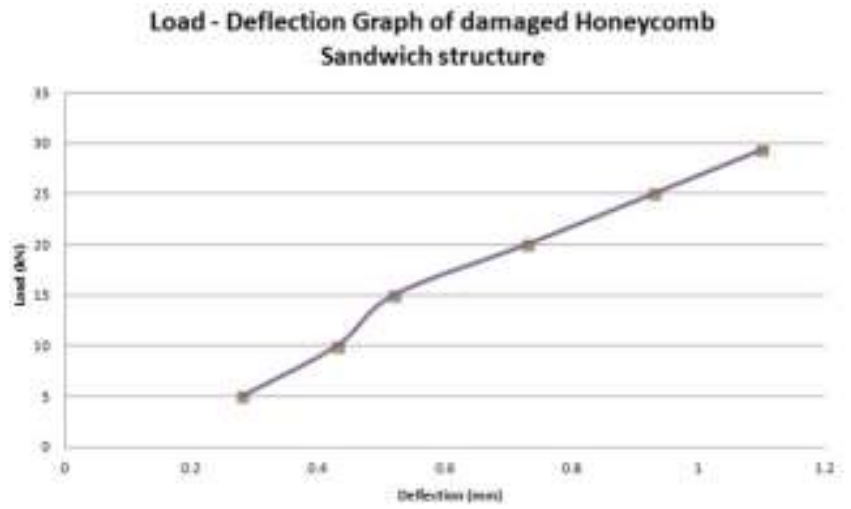

Fig-6: Load-Deflection curve of damaged honeycomb sandwich structure for Edgewise Compression test

The specimen buckled exactly at the point where damage was present. The buckling load for damaged specimen was $29.32 \mathrm{kN}$. Face sheet compressive stress, obtained was 0.9 $\mathrm{kN}$. Eigen buckling analysis was performed for damaged specimen for the ultimate load of $29.82 \mathrm{kN}$ obtained from experiment. The value obtained as buckling load factor was 1. Thus the experimental and analysis values were in good match.
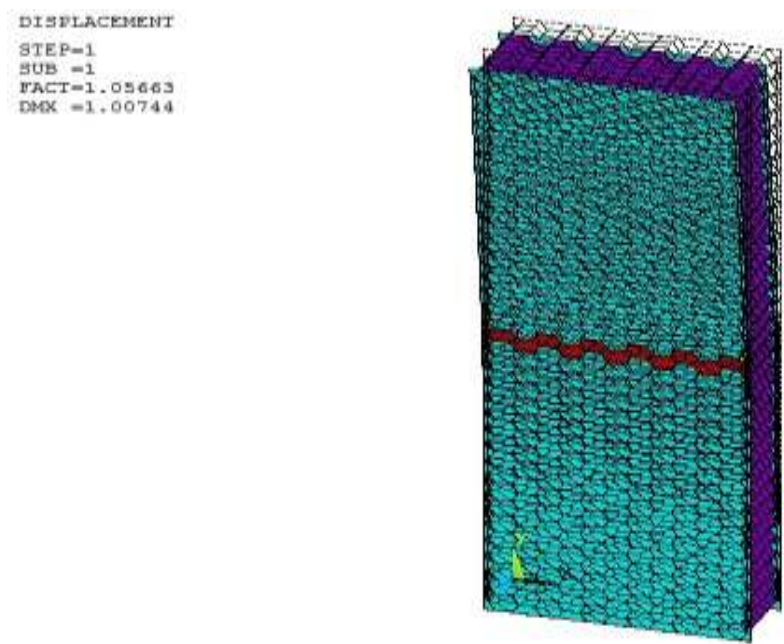

Fig - 7 Buckling analysis of damaged specimen for edgewise compression test

\section{CONCLUSION}

\subsection{Four Point Bending Flexure Test}

1. The ultimate load in tension side of the specimen obtained in four point bending due to flexure was $3.5 \mathrm{kN}$ and tensile strength, $\sigma$ was $0.19 \mathrm{~N} / \mathrm{mm}^{2}$ for both undamaged and damaged specimen due to the fact that the damage present in the specimen was between the support region and shear force between the support region is zero.

2. Strain value obtained was $20 \%$ more for undamaged specimen than damaged specimen.

3. Damaged specimen deflection value was $63 \%$ more than undamaged specimen.

4. Values obtained from finite element analysis and experimental results were in good match with a $3 \%$ variation. 
5. Since difference in ultimate load for both damaged and undamaged specimen was not obtained in four point bending test, edgewise compression test was performed further.

\subsection{Edgewise Compression Test}

1. Specimens in edgewise compression failed due to buckling.

2. The ultimate load obtained in edgewise compression due to buckling was $50.28 \mathrm{kN}$ and compressive strength, $\sigma$ obtained was $1.5 \mathrm{~N} / \mathrm{mm}^{2}$ for undamaged specimen.

3. Skin to core failure at edge took place for undamaged specimen as face sheets are the main load carrying members in the edgewise compression test.

4. The buckling took place exactly at the centre of the specimen where damage was present and the buckling load obtained for damaged specimen was $29.32 \mathrm{kN}$ and its compressive strength, $\sigma$ obtained was $0.9 \mathrm{~N} / \mathrm{mm}^{2}$.

5. Compressive strength obtained was $60 \%$ less for damaged specimen than undamaged specimen.

6. Eigen buckling analysis was performed in Ansys in which the result obtained was in buckling load factor. In buckling analysis, the load given for analysis multiplied by buckling load factor gives the buckling load for that specimen.

7. For the buckling loads obtained from the experiment, the buckling load factor obtained from analysis was 1 . Thus the experimental result and result from finite element analysis were in good match.

8. The load carrying capacity of honeycomb sandwich structure reduces, if a damage is caused to it but can perform its duty with reduced efficiency.

\section{REFERENCES}

[1] Shaik.Nazeer , Shaik Allabakshu, " Design and analysis of honey comb structures with different cases", International Journal of Engineering Development and Research, vol 3, Issue 4, PP 144 156, 2015.

[2] Sakhi Jan, Rafi Ullah khan, Sajjad Ahmad, Muhammad Amjad, abd Saeed Badshah, "Flexural strength of honey comb sandwich structures", International Journal of Applied Sciences and Engineering Research, Vol. 4, Issue 1, pp 83-96, 2015.

[3] A.Gpoichand, R.Mohanrao, N.V.S Sankar, G.Rama Balaji, and P.Sandeep Kumar," Design and Analysis of Copper Honeycomb Sandwich Structure", International Journal of Engineering and Advanced Technology, Vol 2, Issue 4, PP 665-668, 2013.

[4] Kantha Rao and K. Jayathirtha Rao, "Heat Insulation Analysis of an Aluminum Honeycomb Sandwich Structure", International Journal of Mechanical Engineering, Vol 2, Issue 8, PP 1 -12, 2014.

[5] M.S Vaisali, A.S Nisha, " Damage detection using modal strain energy method in honeycomb sandwich beams with multiple delaminations", International journal of innovative science, engineering and technology, vol 2, issue 7, 2015.

[6] Wahyu Lestari and Pizhong Qiao, "Dynamic Characteristics and Effective Stiffness Properties of
Honeycomb Composite Sandwich Structures for Highway Bridge Applications", Journal of Composite Construction, Vol 10, Issue 2, PP 88 -96, 2006,.

[7] HexWeb ${ }^{\mathrm{TM}}$ Honeycomb attributes and properties," A comprehensive guide to standard Hexcel honeycomb materials, configurations and mechanical properties,".

[8] ASTM standard C393/C393M, "Standard test method for core shear properties of sandwich constructions by beam flexure," ASTM international, 2012.

[9] ASTM standard C364/C364M, "Standard test method for edgewise compressive strength of sandwich constructions," ASTM international, 2012.

[10] Banoth Ganesh, B VIjay Kumar, D. Muppala, "Design and structural analysis of aircraft floor panel", International Journal of Advanced Engineering and Global Technology, vol 3 ,issue 12, pp 1451 - 1460, 2015.

[11] Muhammad Yousuf Ayub, Zeeshan Ahmer, Sohail Riffat Khan, Musaddiq Ali Shah, "Mechanical behavior characterization of aluminium based honey comb structure by optimized modeling and numerical simulations", Journal of Space Technology, vol 1, issue 1, pp $26-33,2011$.

[12] LS Dhamande, RV Bhaskar, "Damage detection in aluminium honeycomb structure using vibration analysis," International Journal of Current Engineering and Technology, vol. 4, issue 5, pp 3374 -3379,2014.

[13] Hanfeng Yin, Guilin Wen," Crashworthiness design for honeycomb structures under axial dynamic loading", International Journal of Computational Methods, vol 8, issue 4, pp 863-877, 2011.

[14] Naresh, A.Gopichand, Sunil Ratna Kumar, P.S.B Chowdary, "Numerical Investigation into effect of cell shape on the behavior of honeycomb sandwich panel", International Journal of Innovative Research in Science Engineering and Technology, vol 2, issue 12, pp 8017 $-8022,2013$.

[15] K. Kantha Rao, K. Jayathirtha Rao, “ Thermostructural Analysis of Honeycomb Sandwich Panels", International Journal for Engineering Science and Advanced Technology, vol 2, issue 5, pp 1402-1409, 2012. 